\title{
Menakar Digital Marketing Pada Lembaga Pendidikan Pariwisata
}

\author{
Kadek Ardi Permana (1) \\ Agus Putu Abiyasa (2) \\ Monarch Bali ${ }^{(1)}$ \\ Universitas Pendidikan Nasional ${ }^{(2)}$ \\ ardipermana11@gmail.com ${ }^{(1)}$ \\ abiyasa@undiknas.ac.id ${ }^{(2)}$
}

\begin{abstract}
The purpose of this study is to find out how the role of digital marketing in the Tourism Education Institute. This research was carried out in tourism education institutions in the Province of Bali that have carried out digital marketing strategies. Given that at this time digital marketing is becoming a trend among businessmen and in educational institutions. Especially now that the millennial generation is looking for information through the internet or accessing various kinds of social media that are currently being loved by young people throughout the country. There are a number of questions given to participants and informants in this study where participants and informants are new students in tourism education institutions. The selection of informants in this study is by using the purposive sampling method and the technique of validating the data using the source triangulation technique. The result of this research is that currently the preferred marketing strategy is in a conventional way where this method is still the favorite way for the public, especially new students to get information about the Tourism Education Institution which they will choose compared to digitalization, which is still an option the second to introduce Tourism Education Institutions to the public, especially new students, is moreover the uneven knowledge and lack of connections from internet networks in the Tourism Institution area which causes this digital marketing to be less optimal.
\end{abstract}

Keywords: Digital Marketing; Business Strategy; Tourism 


\begin{abstract}
ABSTRAK
Tujuan dari penelitian ini adalah untuk mengetahui bagaimana peranan digital marketing pada Lembaga Pendidikan Pariwisata. Penelitian ini dilakukan di lembaga pendidikan pariwisata yang berada di Provinsi Bali yang sudah melakukan strategi digital marketing. Mengingat pada saat ini digital marketing sedang menjadi tren dikalangan pembisnis maupun di lembaga pendidikan. Apalagi saat ini anak-anak generasi milenial lebih banyak mencari informasi melalui internet atau mengakses berbagai macam sosial media yang saat ini sedang digandrungi oleh para anak muda di seluruh negeri. Terdapat beberapa pertanyaan-pertanyaan yang diberikan kepada partisipan dan informan dalam penelitian ini yang dimana partisipan dan informan ini adalah mahasiswa baru yang ada di lembaga pendidikan pariwisata. Pemilihan dari informan penelitian ini adalah dengan cara menggunakan metode purposive sampling serta teknik pengabsahan data menggunakan teknik triangulasi sumber. Hasil dari penelitian ini adalah saat ini strategi pemasaran yang disukai adalah dengan cara konvensional yang dimana cara ini masih menjadi cara terfavorit bagi masyarakat khususnya mahasiswa baru untuk mendapatkan informasi mengenai Lembaga Pendidikan Pariwisata yang akan dipilihnya dibandingkan dengan cara digitalisasi, yang dimana digitalisasi ini masih menjadi opsi kedua untuk mengenalkan Lembaga Pendidikan Pariwisata kepada masyarakat khususnya mahasiswa baru terlebih lagi masih belum meratanya pengetahuan serta minimnya koneksi dari jaringan internet di daerah Lembaga Pariwisata yang menyebabkan kurang optimalnya penerapan digital marketing ini.
\end{abstract}

Kata kunci : Digital Marketing; Strategi Bisnis; Pariwisata 


\section{PENDAHULUAN}

Pendidikan memiliki peran yang sangat penting untuk menjamin bagaimana kelangsungan hidup suatu bangsa dan negara, karena pendidikan merupakan wadah dalam meningkatkan kualitas sumber daya manusia (Darma dkk., 2019). Keberhasilan bagi bangsa dan negara sangat ditentukan oleh bagaimana keberhasilan dalam memperbaiki dan memperbaharui pendidikan generasi selanjutnya, dimana bangsa yang mempunyai sumber daya manusia yang baik dan mampu bersaing adalah mereka yang maju dalam dunia Pendidikan (Hidayat, 2017; Darma dkk., 2019).

Dampak pendidikan dapat mempercepat kemajuan dan pembangunan bangsa itu sendiri dikarenakan sumber daya manusia yang mampu bersaing serta melimpah di dalam suatu negara. Dari masa ke masa, pendidikan senantiasa berubah terus menerus seiring dengan perkembangan zaman (Astuti dan Darma, 2019). Begitu pula dengan perubahan yang terjadi di dalam berbagai industri. Menurut Bali dan Darma (2019) serta Dewi dan Darma (2019) yang dikutif dari berbagai sumber menyimpulkan bahwa revolusi industri yang pertama terjadi yakni pada tahun 1784 dimana penemuan mesin uap dan mekanisasi mulai menggantikan pekerjaan manusia, revolusi yang kedua terjadi pada akhir abad ke-19 yang dimana mesin-mesin produksi yang menggunakan tenaga listrik untuk kegiatan produksi secara masal, dan revolusi ketiga terjadi pada tahun 1970 ditandai dengan berkembangnya penggunaan teknologi komputer (Prasetyo dan Sutopo, 2018; Darma, 2019). Pada saat ini yang terjadi adalah revolusi ke empat (4.0) dimana perkembangan teknologi yang pesat dari teknologi sensor, interkoneksi, dan analisis data memunculkan gagasan untuk mengintegrasikan seluruh teknologi tersebut ke dalam berbagai bidang industri kendati hal ini industri 4.0 diumumkan secara apriori karena peristiwa nyatanya belum terjadi dan masih dalam bentuk gagasan (Drath dan Horch, 2014) dalam (Prasetyo dan Sutopo, 2018).

Perubahan ini diikuti oleh berkembangnya proses pembelajaran serta proses operasional bagi para pelaku industri jasa khusus di bidang Pendidikan (Darma dkk., 2019; Darma, 2018; Darma, 2019). Saat ini perkembangan teknologi informasi sangatlah berkembang pesat dari tahun ke tahun bahkan dari hari ke hari, hal ini menyebabkan promosi yang dulunya dilakukan oleh perusahaan secara konvensional (tradisional) sekarang sedikit demi sedikit mulai bergeser dengan menggunakan teknologi (internet) (Darma, 2019; Adnyasuari dan Darma, 2017; Darma, 2006). Anak-anak generasi milenial saat ini lebih banyak mencari informasi melalui internet atau mengakses berbagai macam sosial media yang saat ini sedang digandrungi oleh para anak muda di seluruh negeri. Menurut Ferdiana dan Darma 
(2019), pengguna media internet di Indonesia terus mengalami peningkatan yaitu mencapai angka 63 juta orang, dimana 95 persen penggunaan untuk media sosial, hal tersebut berdasarkan data kementerian komunikasi dan informasi tahun 2015.

Sebagian besar orang berpendapat bahwa potensi dan manfaat dari Industri 4.0 dapat memaksimalkan kecepatan dan ketepatan produksi, peningkatan layanan kepada pelanggan dan dapat meningkatkan pendapatan perusahaan (Dewi dan Darma, 2019; Danuarta dan Darma, 2019). Dalam hal ini diharapkan terwujudnya potensi manfaat tersebut akan memberi dampak positif terhadap perekonomian suatu negara (Maharani dan Darma, 2018).

Namun, jika kita telaah lebih jauh lagi, pada saat ini masyarakat di Indonesia khususnya pada provinsi yang masih berkembang dan beradaptasi dengan adanya perubahan tersebut tentunya terdapat pro kontra dalam penerapan digitalisasi ini, yang mengakibatkan dilema bagi para pelaku usaha khususnya lembaga pendidikan untuk memutuskan strategi yang tepat dalam mengambil hati para konsumennya

Berdasarkan fenomena tersebut, peneliti ingin mengukur seberapa nyaman dan efektifkah digitalisasi ini jika diterapkan pada Sekolah Tinggi atau Perguruan Tinggi yang bergerak di bidang pariwisata guna menjawab pro kontra ditengah masyarakat serta dilema yang dihadapi para pelaku bisnis yang bergerak di bidang jasa khususnya lembaga pendidikan. Maka dari itu, peneliti mengangkat judul penelitian yakni "Menakar Digital Marketing di Lembaga Pendidikan Pariwisata".

\section{Digital Marketing}

Menurut Katawetawaraks dan Wang (2011) menjelaskan bahwa belanja online adalah kegiatan pembelian produk (baik barang ataupun jasa) melalui media internet. Kegiatan digital marketing itu sendiri merupakan pengembangan dari kegiatan pemasaran tradisonal. Sarwono dan Prihartono (2012) mengatakan bahwa teknik yang memudahkan akses dan publikasi informasi menggunakan interaksi social melalui social media. Sosial media menjadi sangat popular karena memberikan kemudahan dan kesempatan bagi orang-orang untuk dapat terhubung secara online baik dalam urusan bisnis, politik maupun hubungan secara personal (Pradiani : 2017; Agung dan Darma, 2019).

Digital marketing bukan hanya berwirausaha melainkan bagaimana cara merubah industri dan meremajakan pendekatan-pendekatan lama dengan cara-cara baru untuk berinovasi di masa depan. Maka dari itu seseorang yang menerapkan digital marketing ini haruslah mempunyai cara berpikir yang inovatif untuk mengembangkan segala potensi yang 
ada, dimana nantinya inovasi ini dapat bersaing dan diterima di masyarakat (Kasali, 2017; Handika, Maradona dan Darma, 2018).

\section{Customer Behaviour}

Sebelum menentukan sebuah strategi yang akan diterapkan oleh perusahaan, perusahaan harus menganalisa terlebih dahulu bagaimanakah perilaku konsumen atau pelanggan yang akan menjadi target pasar dalam memasarkan suatu produk. Perilaku konsumen adalah sebuah tindakan yang langsung terlibat dalam mendapatkan, mengkonsumsi, dan menghabiskan suatu barang dan jasa serta bagaimana proses yang mendahului dan menyusul dari suatu tindakan yang dilakukan ini (Engel, 2010; Kanten dan Darma, 2017). Dalam jurnal Khorinnisa et al (2016) mengatakan bahwa perilaku konsumen akan muncul karena adanya kebutuhan dan keinginan seseorang untuk memperoleh sesuatu (didukung juga hasil penelitian dari Maharani dan Darma, 2018).

Menganalisa perilaku konsumen adalah hal yang sangat penting bagi sebuah perusahan dalam mencetuskan sebuah strategi yang akan dibangun. Keinginan dalam hal ini minat dari konsumen dapat menjadi sebuah acuan untuk perusahaan dalam mebuat sebuah strategi, yang menyebabkan konsumen ingin untuk melakukan keputusan untuk mengkonsumsi produk yang ditawarkan oleh perusahaan.

\section{Minat}

Menurut Naas (2016) menyatakan bahwa minat adalah sesuatu hasil pengalaman yang tumbuh dan dianggap bernilai oleh individu adalah kekuatan yang mendorong seseorang itu untuk berbuat sesuatu. Sedangkan dalam penelitian Fitri (2013) mengatakan minat dapat dipengaruhi oleh jenis kelamin, inteligensi, kesempatan, lingkungan, teman sebaya, kesanggupan dan banyak faktor lainnya. maka dapat dikatakan bahwa minat adalah ketertarikan seseorang terhadap sesuatu objek yang dipengaruhi oleh jenis kelamin, kesempatan, lingkungan, dan keinginan serta beberapa faktor lain yang dapat dijadikan pengalaman yang bernilai serta dapat mendorong bagaimana tindakan terhadap kegiatan atau objek tertentu.

\section{Keputusan Pembelian}

Tjahjaningsih dan Yuliani (2009) menyatakan keputusan pembelian merupakan tahapan proses keputusan dimana konsumen secara aktual melakukan pembelian suatu produk. Suharno (2010) keputusan adalah tahapan dimana konsumen telah menentukan pilihannya dalam melakukan pembelian produk untuk dikonsumsi. Keputusan yang dilakukan oleh 
konsumen dapat ditentukan melalui bagaimana variasi yang diberikan oleh perusahaan kepada konsumen, terdapat kesesuaian terhadap keinginan atau kebutuhan. Maka dapat disimpulkan bahwa keputusan adalah dimana konsumen melakukan pembelian produk dan telah menentukan pilihannya dalam hal memilih produk yang diawali oleh adanya kesadaran atas pemenuhan kebutuhan dan keinginan (Handika dkk., 2018).

\section{Kerangka Pemikiran}

Berikuat adalah gambaran kerangka penelitian dari penelitian ini :

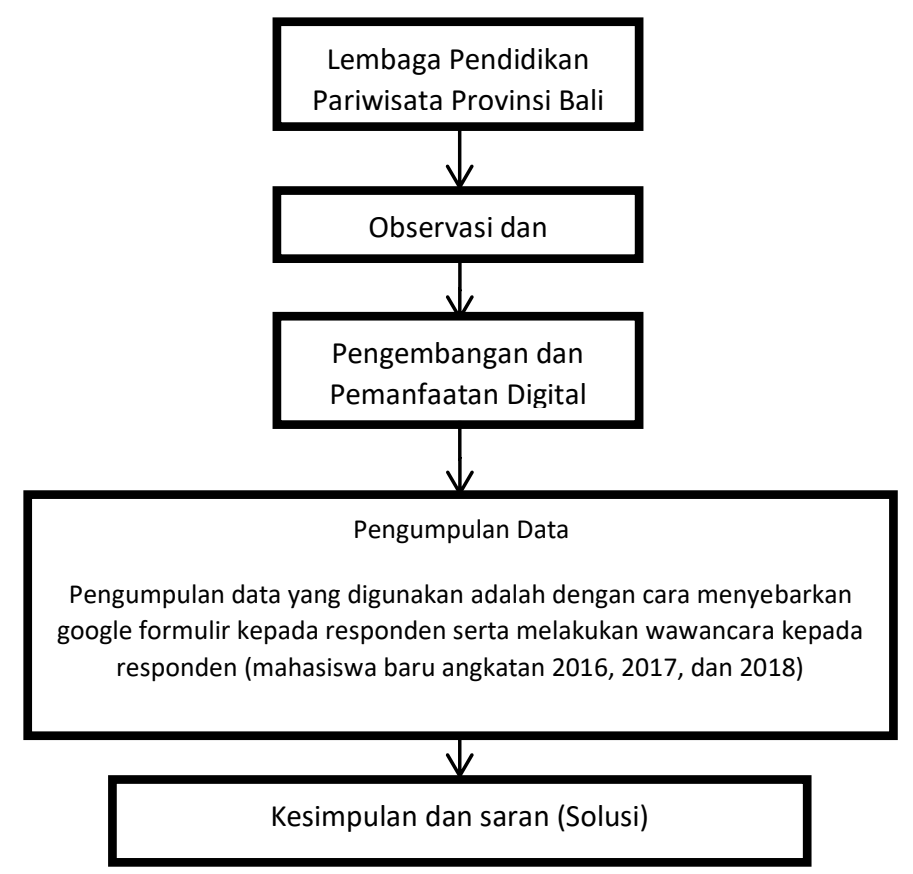

Gambar 1. Kerangka Pemikiran

Sumber: dikembangkan oleh peneliti

\section{METODE PENELITIAN}

Penelitian ini dilakukan di lembaga pendidikan pariwisata yang terdapat di Provinsi Bali. Yang dimana lembaga pendidikan pariwisata yang diteliti telah dianggap melakukan digital marketing, baik melalui web, social media, maupun menggunakan media internet lainnya. Lembaga pendidikan pariwisata yang dimaksud adalah lembaga pendidikan pariwisata Sekolah Tinggi Pariwisata (STP) Bali, Monarch Bali, Monarch Gianyar, Elizabeth Internasional, Politeknik Negeri Bali, dan Universitas Udaya.

Desain penelitian pada penelitian ini akan menggunakan pendekatan kualitatif dengan metode analisis deskriptif. Aktivitas pada penelitian ini dicirikan oleh kegiatan pengumpulan data, menggambarkan, dan menafsirkan data tentang situasi yang dialami pada lokasi penelitian (Cresswell, 1994). 
Peneliti ingin menggunakan metode kualitatif dimaksudkan untuk menemukan dan memahami apa yang akan diteliti. Pendekatan kualitatif diyakini mampu mengarahkan pencarian-pencarian konsep baru melalui intepretasi proses dan makna dari suatu penelitian yang selanjutnya dapat digunakan untuk membangun prediksi dan memberikan eksplanasi terhadap apa yang diteliti.

\section{PEMBAHASAN}

Semakin berkembangnya teknologi diharapkan industri yang ada saat ini mampu beradaptasi dengan perubahan yang dimana pada saat ini diIndonesia sendiri telah menghadapi era industry 4.0 yang mengakibatkan segala kegiatan marketing dan operasional diharapkan dapat dilakukan menggunakan teknologi, namun dalam hasil penelitian yang telah dilakukan, partisipan dalam penelitian ini lebih banyak memberikan jawaban dengan cara konvensional dibandingkan dengan cara digitalisasi ditambah lagi Lembaga Pendidikan Pariwisata itu sendiri belum secara sempurna dalam menerapkan digitalisasi ini. Berikut hasil kuesioner dan wawancara singkat yang dilakukan oleh peneliti :

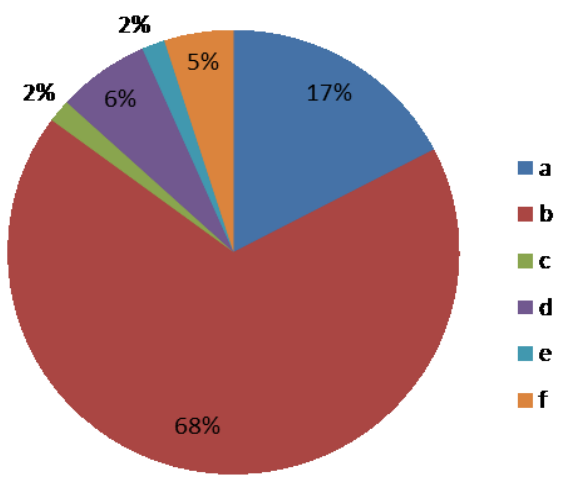

\section{Gambar 2. Diagram Pertanyaan Pertama}

Sumber : data diolah peneliti

Dari pertanyaan pertama yang telah diberikan kepada partisipan, sebesar $68 \%$ partisipan menjawab "citra dari perguruan atau sekolah tinggi ini baik" berbanding terbali yang diharapkan oleh peneliti dimana hanya 5\% partisipan yang menjawab "sering melihat iklan perguruan atau sekolah tinggi ini di Web atau Social Media". Ini berarti dapat disimpulkan bahwa mahasiswa baru yang ingin melanjutkan pendidikannya melihat lebih banyak dari bagaimana citra Lembaga Pendidikan Pariwisata itu sendiri bukan dari seberapa sering mereka melihat iklan yang dilakukan oleh Lembaga Pendidikan tersebut melalui internet serta social media. 


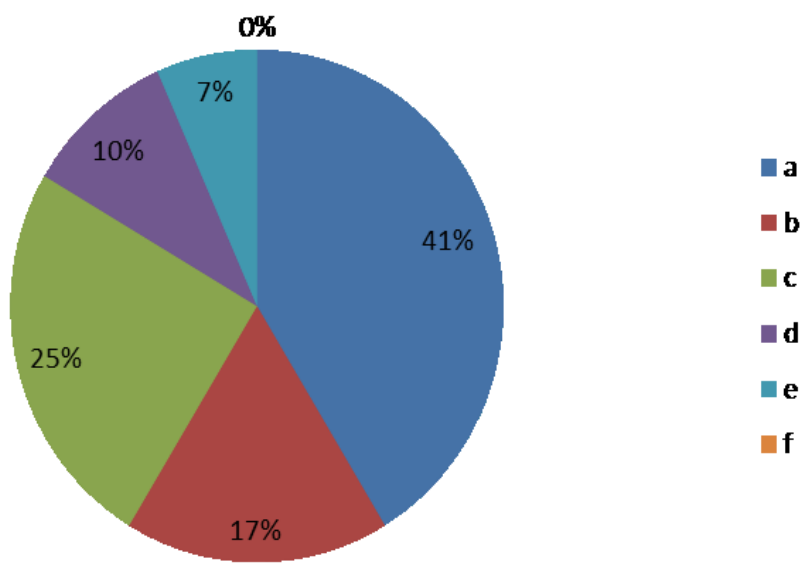

\section{Gambar 3. Diagram Pertanyaan Kedua}

Sumber : data diolah peneliti

Dari pertanyaan kedua yang telah diberikan kepada partisipan, sebesar $41 \%$ partisipan menjawab "konvensional (media elektronik, media cetak, dan sosialisasi)" lebih banyak dari partisipan yang menjawab yang menggunakan digitalisasi (WEB, Instagram, dan Facebook) yang masih-masing memiliki nilai sebesar 10\%, 7\%, dan 0\%. Ini berarti dapat disimpulkan bahwa mahasiswa baru yang ingin melanjutkan pendidikannya lebih banyak mengetahui infomasi tentang perguruan atau sekolah tinggi mereka melalui cara konvensional dibandingkan dengan cara digitalisasi.

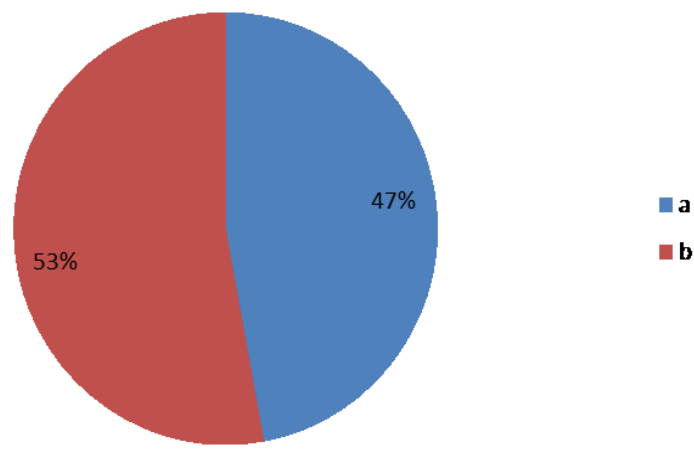

\section{Gambar 4. Diagram Pertanyaan Ketiga}

Sumber : data diolah peneliti

Dari pertanyaan ketiga yang telah diberikan kepada partisipan, sebesar 53\% partisipan menjawab bagaimanakah proses atau cara anda mendaftar pada perguruan atau sekolah tinggi? adalah "menggunakan formulir berupa hard copy (kertas)" lebih banyak 
dibandingkan dengan "Melewati link (e-form)" yakni sebanyak 43\% partisipan yang menjawab jawaban tersebut. Ini berarti dapat disimpulkan bahwa Lembaga Pendidikan Pariwisata masih menggunakan cara-cara konvensional dalam melakukan pendaftaran, yang dimana proses digitalisasi masih belum bisa menggantikan cara-cara konvensional tersebut.

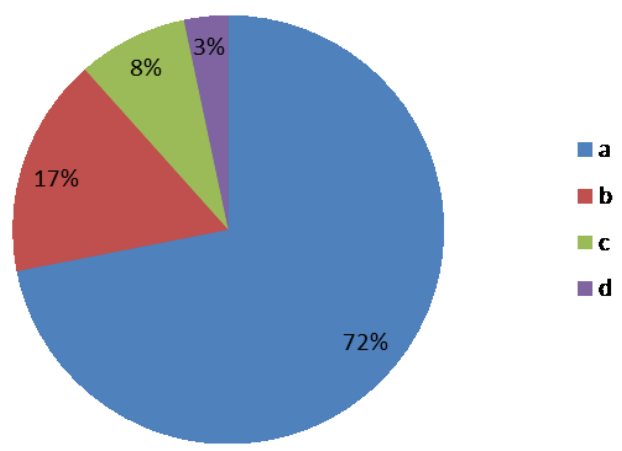

\section{Gambar 5. Diagram Pertanyaan Keempat}

Sumber : data diolah peneliti

Dari pertanyaan keempat yang telah diberikan kepada partisipan, sebesar $72 \%$ partisipan menjawab cara yang paling mereka sukai adalah dengan cara "konvensional (media elektronik, media cetak, dan sosialisasi)" sedangkan dengan melalui "WEB, Instagram, dan Facebook" hanya 17\%, 8\%, dan 3\% partisipan yang menyukai cara tersebut. Ini berarti dapat disimpulkan bahwa mahasiswa baru angkatan 2016, 2017, dan 2018 masih menyukai cara-cara konvensional untuk memperoleh informasi dari Lembaga Pendidikan Pariwisata yang akan dipilihnya disbanding melalui Web, Instagram, atau Facebook. .

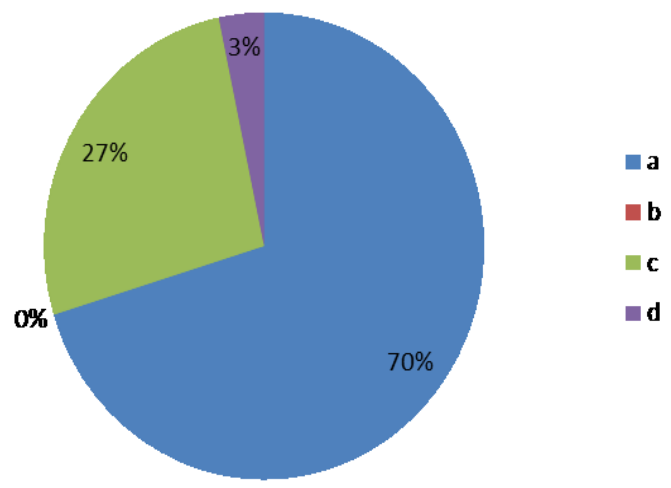

\section{Gambar 6. Diagram Pertanyaan Kelima}

Sumber : data diolah peneliti 
Dari pertanyaan kelima yang telah diberikan kepada partisipan, sebesar $70 \%$ partisipan menjawab cara promosi yang digunakan langsung dapat menarik minat mahasiswa baru angkatan 2016, 2017, dan 2018 sedangkan sebesar 27\% menjawab "menunggu keputusan orang tua, dan sebesar 3\% menjawab konten yang diberikan tidak membuat mereka tertarik untuk langsung mendaftar. Namun dalam hal ini terdapat jawaban pada huruf "a" yang dimana jawaban tersebut dari jawaban pertanyaan nomer 4 sebanyak 70\% menjawab "Ya" yang dimana jawaban "Ya tersebut adalah $84 \%$ jawab menjawab untuk konvensional dan $16 \%$ menjawab untuk digital marketing yang dilakukan oleh Lembaga Pendidikan Pariwisata. Ini dapat disimpulkan, mahasiswa angkatan baru angkatan 2016, 2017, dan 2018 lebih menyukai cara konvensional dibandingkan cara digital marketing, namun digital marketing sendiri masih mendapatkan tempat di mahasiswa baru walaupun hanya $16 \%$ yang menyukainya.

Demikian juga berdasarkan hasil wawancara yang telah dilakukan oleh peneliti kepada informan yang dilakukan dengan menggunakan alat elektronik (handphone) untuk merekam percakapan dengan informan terkait, berikut adalah pernyataan mahasiswa baru 2016 terkait bagaimana penerapan digital marketing di salah satu kampus yang ia sukai, berikut adalah penyataannya :

"Menurut saya, iklan menggunakan medsos tidak begitu saya suka karena informasi yang diberikan cenderung tidak lengkap dan harus membuka web dari sekolah itu jadi saya malas untuk membukanya lagi, memang saya menggunakan medsos dan menyukai hal-hal yang menurut saya menarik tetapi untuk keperluan sekolah saya lebih suka untuk pergi ketemaptnya langsung.. Tetapi jika dilakukan dengan cara sosialisasi saya dapat langsung bertanya dan mendapatkan jawab dari pertanyaan saya agar saya tau bagaimana situasi lingkungan dari sekolah tersebut. Kalau penerapan dari medsosnya sendiri sih sudah bagus tapi saya masih suka dengan cara sosialisasi ketimbang harus lewat medsos atau digital karena saya belum terlalu paham juga".

Hal yang sama juga dikatakan oleh informan kedua yakni mahasiswa baru angkatan 2017, berikut adalah penyataannya:

"Kalau saya paling cuma lihat-lihat diberanda habis itu saya kembali lagi mencari yang lain, karena menurut saya lebih baik langsung ke kampus agar saya mengetahui lebih detail bagaimana alur pendafatarannya, dan juga kalau dirumah dan lingkungan saya untuk koneksi internet agak susah untuk mendaftar secara online. Tapi saya sering lihat baliho dari kampus yang saya cari lebih banyak disana informasinya ketimbang di medsos. Kalau saya untuk menerapannya masih belum 
begitu maksimal, karena juga kita disuruh kekampusnya untuk melakukan pendaftaran juga".

Pernyataan serupa yang dikatakan oleh mahasiswa baru angkatan 2018, berikut adalah pernyataannya :

"Ketika saya mengetahui kampus ini, saya mengetahuinya lewat teman saya, ketika itu saya mencari informasinya lewat aplikasi google untuk mencvari tahu informasinya, Cuma pas saya buka informasinya tidak begitu lengkap jadi besoknya saya bersama teman saya mencari tau ke kampus saya ini. Kalau di medsos saya belum pernah lihat iklan dari kampus ini. Sewaktu saya mendaftar saya mendaftar lewat front office nya langsung jadi saya menggunakan kertas disana, dan saya sebelum mendaftar saya meminta pertimbangan terlebih dahulu kepada orang tua saya sebelum saya melakukan pendaftaran ulang. Kalau penerapan digital marketingnya menurut saya sih masih belum terlalu bagus karena saya juga jarang lihat di medsos sama ujungujungnya saya juga disuruh kekampus buat daftar dan ngurus yang lain-lain”.

Dari pernyataan-pernyataan partisipan dan informan diatas, peneliti dapat menyimpulkan bahwa saat ini cara konvensional masih menjadi cara terfavorit bagi masyarakat khususnya mahasiswa baru untuk mendapatkan informasi mengenai Lembaga Pendidikan Pariwisata yang akan dipilihnya dibandingkan dengan cara digitalisasi, yang dimana digitalisasi ini masih menjadi opsi kedua untuk mengenalkan Lembaga Pendidikan Pariwisata kepada masyarakat khususnya mahasiswa baru terlebih lagi masih belum meratanya pengetahuan serta minimnya koneksi dari jaringan internet di daerah Lembaga Pariwisata yang menyebabkan kurang optimalnya penerepan digital marketing ini. Dimana hal ini juga dikemukakan oleh Abdu (2018) yang mengatakan bahwa Digital Marketing hanya berpengaruh sebesar 15,1\% terhadap pembentukan citra perusahaan di masyarakat. Sedangkan penelitian yang dilakukan oleh Riskyawan dan Ervianty (2019) mengatakan bahwa pemasaran menggunakan media social (instagram) sudah efektif namun belum secara optimal dipergunakan, sehingga perlu adanya pendekatan kembali kepada konsumen melaui via telephone atau langsung memberitahu kepada konsumen secara direct (langsung). 


\section{DAFTAR PUSTAKA}

Abdu, R. (2017). Pengaruh Digital Marketing Terhadap Corporate Image Pada Pt Ahm Di Kota Bandung. e-Proceeding of Applied Science: 4 (2)

Adnyasuari, P.A.S., and Darma, G.S. (2017). Technology Acceptance Model dan ESatisfaction in Mobile Banking, Jurnal Manajemen \& Bisnis, 14 (2): 1-12.

Agung, N.F.A., and Darma, G.S. (2019). Opportunities and Challenges of Instagram Algorithm in Improving Competitive Advantage, International Journal of Innovative Science and Research Technology, 4 (1): 743-747.

Alma, B. (2007). Manajemen Pemasaran Dan Pemasaran Jasa. Bandung: Alfabeta.

Arianti, N.L.N., Darma, G.S., Maradona, A.F., and Mahyuni, L.P. (2019). Menakar Keraguan Penggunaan QR Code Dalam Transaksi Bisnis, Jurnal Manajemen \& Bisnis, 16 (2): $67-78$.

Astuti, K. A., and Darma, G. S. (2019). Community-based tourism: measuring readiness of artificial intelligence on traditional village, International Journal of Social Sciences and Humanities, 3 (3): 81-89.

Bali, I.N.A.P., and Darma, G.S. (2019). Menguji Kesiapan Pengelolaan Desa Berbasis Manajemen Modern Guna Menghadapi Era Revolusi Industri 4.0, Jurnal Manajemen \& Bisnis, 16 (2): 1-13.

Darma, G.S. (2006). Optimalisasi Penggunaan Teknologi Informasi dan Kinerja Organisasi. Denpasar: Undiknas Press.

Darma, G.S. (2006). Manajemen Strategi: Solusi dalam Dunia Nir Kabel. Denpasar: Undiknas Press.

Darma, G.S. (2006). Mobile Marketing: Sebuah Strategi Keunggulan Bersaing Online. Denpasar: Undiknas Press.

Darma, G.S. (2019). Kacamata Media, Kesuksesan Bersyarat. Indonesia: Pustaka Larasan Press.

Darma, G.S., Apollo, A., Rusmanda, G., and Umar, Y. (2019). Digital Education 4.0. Indonesia: Cakra Media Utama Press.

Danuarta, G.L.N., and Darma, G.S. (2019). Determinants of Using Go-Pay and Its Impact on Net Benefits, International Journal of Innovative Science and Research Technology, 4 (11): 173-182.

Dewi, M.V.K., and Darma, G.S. (2019). The Role of Marketing \& Competitive Intelligence In Industrial Revolution 4.0, Jurnal Manajemen \& Bisnis, 16 (1): 1-12. 
Drath, R., \& Horch, A. (2014). Industrie 4.0: Hit or hype?[industry forum], IEEE industrial electronics magazine, 8 (2): 56-58.

Engel, F. Roger, J.B.D., dan Miniard W, P. (2010). Perilaku Konsumen. Alih Bahasa Budiyanto. Jakarta: Binarupa Aksara, Jilid 1.

Ferdiana, A.M.K., and Darma, G.S. (2019). Understanding Fintech Through Go-Pay, International Journal of Innovative Science and Research Technology, 4 (2): 257-260.

Fitri, K. (2013). Pengaruh Jenjang Karir dan Tantangan Pekerjaan Terhadap Minat Fresh Graduate Fkip Universitas Riau Pada Profesi Sales. Tahun IV No. 10.

Handika, M.R., Maradona, A.F., and Darma, G.S. (2018). Strategi Pemasaran Bisnis Kuliner Menggunakan Influencer Melalui Media Sosial, Jurnal Manajemen \& Bisnis, 15 (2): 188-199.

Hidayat, H.F. (2017). Strategi Manajemen Marketing Madrasah Aliyah Negeri (Man) Klaten Tahun 2016/2017.

Moleong, L. (2000). Metode Penelitian Kualitatif. Bandung: Remaja Rosdakarya.

Kanten, I.K., and Darma, G.S. (2017). Consumer Behaviour, Marketing Strategy, Customer Satisfaction, and Business Performance, Jurnal Manajemen \& Bisnis, 14 (2): 143-165. Khoirinnisa, E, Et Al. (2016). Analisis Perilaku Konsumen Dalam Keputusan Pembelian Produk Kaki Naga (Studi Kasus Di CV. Bening Jati Anugrah, Kabupaten Bogor).

Mardiani, I.E., dan Orland Jorge Imanuel. (2013). Analisis Keputusan Pembelian Konsumen Melalui Media Online (E-Marketing), Jurnal Ekonomi, 4 (2).

Maharani, I.G.A.P.D., and Darma, G.S. (2018). Consumer Purchasing Behavior Analysis on Impulse Buying, Jurnal Manajemen \& Bisnis, 15 (3): 16-37.

Naas, M.A. (2016). Pengaruh Iklan Politik Melalui Media Sosial (Facebook) Terhadap Minat Memilih Kepala Daerah Di Kota Samarinda.

Payne, A. (2007). Pemasaran Jasa. Terjemahan Fandi Tjiptono. Jakarta: Andi.

Pradiani, T. (2017). Pengaruh Sistem Pemasaran Digital Marketing Terhadap Peningkatan Volume Penjualan Hasil Industri Rumahan.

Prasetyo, H., \& Sutopo, W. (2018). Industri 4.0: Telaah Klasifikasi Aspek Dan Arah Perkembangan Riset, Jurnal Teknik Industri, 13 (1).

Riskyawan, A.V., \& Ervianty, R.M. (2019). Penggunaan Media Komunikasi Pemasaran Digital sebagai Alat Pencapaian Kesadaran Merek pada Produk Kitchenindo.

Strauss, dkk. (2009). E-Marketing $5^{\text {th }}$ Edition. Upper Saddle, New Jersey: Prientice-Hall, Inc. Sugiyono. (2013). Metodelogi Penelitian Kuantitatif, Kualitatif Dan R\&D. Bandung: Alfabeta. 
Suharno. (2010). Marketing in Practice. edisi pertama. Yogyakarta: Graha Ilmu.

Tjiptono, F. (2008). Strategi Pemasaran. Edisi Ketiga. Yogyakarta: Andi.

Widyanto, Dkk. (2017). Pengaruh E-Wom Di Instagram Terhadap Minat Berkunjung Dan Dampaknya Pada Keputusan Berkunjung.

Wind, J., dan Mahajan, V. (2002). Digital Marketing, Symphonya. Emerging Issues in Management (symphonya.unimib.it). 